\title{
Experimental Study on the Steel-Concrete Composite Girder Joint of a Single Pylon Cable-Stayed Bridge
}

\section{Xu S', Yang YW'1, Lu Deng ${ }^{2 *}$ and Liu B ${ }^{1}$}

${ }^{1}$ The Second Engineering Co., LTD, China Railway No.9 Group, China

${ }^{2}$ College of Civil Engineering, Hunan University, Hunan, China

\begin{abstract}
Hybrid girder cable-stayed bridges have been widely used around the world due to its advantages including the large-span viability of the main span with steel girder and the counterweight effect of the side span with concrete girder The steel-concrete composite joint in hybrid girder cable-stayed bridges plays an important role in connecting the steel girder with the concrete girder and transferring the internal forces between two segments of different materials. Therefore, the performance and reliability of the composite joint is of great importance to such bridges. In order to examine the performance of the steel-concrete composite joint of a hybrid girder cable-stayed bridge with single pylon, a 1/4 scaled joint model was fabricated in the laboratory and static test was conducted. The stress distribution and the relative slip between concrete and steel under the combined action of axial force and bending moment were investigated. The test results showed that the maximum stresses of the steel and concrete components are within the allowable limits and the internal forces can be transferred smoothly between the steel girder and the concrete girder via the composite joint. The findings from this study provide useful reference and guidance for the design and testing of steel-concrete composite joints in hybrid girder cable-stayed bridges.
\end{abstract}

Keywords: Hybrid girder; Cable-stayed bridge; Experimental study; Composite girder joint; Scaled model

\section{Introduction}

During the past two decades, a number of hybrid-girder cablestayed bridges have been constructed around the world due to its advantages including the large-span viability of the main span with steel girder and the counterweight effect of the side span with concrete girder [1-3]. For hybrid girder cable-stayed bridges, the steel-concrete composite joint plays an important role in connecting the steel girder with the concrete girder and transferring the internal forces between the two segments of different materials.

In order to study the performance of the hybrid girder composite joint and to validate its force transfer mechanism, plenty of experimental and numerical studies have been conducted [3-7]. Chen et al. [4] carried out tests on a $1 / 2$ scaled model of the hybrid girder composite joint for the Taoyaomen Bridge with single-cell box girder in China, and investigated the stress distribution and the shear lag effect of the joint. He et al. [7] also conducted tests on a 1/2 scaled joint model of a hybrid girder cable-stayed bridge. The stress distribution, the relative slip between steel and concrete, and the crack resistance were investigated. However, due to the limitation of the experimental condition, only one-half cross section of the box girder was adopted in the test. Cheng et al. [3] studied the mechanical performances of the steel-to-concrete deck transition zone of a hybrid box-girder cable-stayed bridge based on the static test on five local specimens taken from the full scale bridge deck. They also developed a nonlinear three-dimensional finiteelement model, which was verified with the test results, to simulate the specimens. The load-slip curves, stress distribution and failure modes were investigated in their study. However, the results obtained may not be able to truly reflect the global performance of the joint because the tests were conducted on local specimens only. He et al. [5] and Xiao et al. [6] both conducted pull-out tests on the perfobond strip connectors used in the steel-concrete composite joint of hybrid cable-stayed bridges but they focused on different issues. He et al. [5] studied the failure modes, ductility, and ultimate shear resistance of the perfobond strip connectors while Xiao et al. [6] investigated the effects of push-out test arrangement, plate thickness, and concrete compressive strength on the mechanical behavior of the perfobond strip connectors. In addition, experimental and theoretical studies were also conducted to validate the design methods of hybrid bridges [8-14].

It is noted that although the steel-concrete composite joint of hybrid-girder cable-stayed bridges has been intensively studied from different aspects, very few research work has focused on the global performance of the composite joint. In order to investigate the performance of the steel-concrete composite joint of a hybrid girder cable-stayed bridge with single pylon, a 1/4 scaled joint model was fabricated in the laboratory and static test was conducted. The stress distribution and the relative slip between concrete and steel under the combined action of axial force and bending moment were investigated. The test results showed that the maximum stresses in the steel and concrete components are within the allowable limits and that the maximum compressive stresses occurred at the section of steel girder rather than the steel-concrete composite section. The findings from the study provide useful reference and guidance for the design and testing of steel-concrete composite joints in hybrid girder cable-stayed bridges.

\section{Bridge under Consideration}

The bridge under consideration is a hybrid girder cable-stayed highway bridge with a single pylon and a single cable plane. The bridge

*Corresponding author: Lu Deng, Hunan Provincial Key Laboratory for Damage Diagnosis for Engineering Structures, College of Civil Engineering, Hunan University, Changsha 410082, Hunan, China, Tel: 86-731-88823320; E-mail: denglu@hnu.edu.cn

Received December 07, 2017; Accepted December 13, 2017; Published December 19, 2017

Citation: Xu S, Yang YW, Deng L, Liu B (2017) Experimental Study on the SteelConcrete Composite Girder Joint of a Single Pylon Cable-Stayed Bridge. J Steel Struct Constr 4: 139. doi: 10.4172/2472-0437.1000139

Copyright: (c) $2017 \mathrm{Xu} \mathrm{S}$, et al. This is an open-access article distributed under the terms of the Creative Commons Attribution License, which permits unrestricted use, distribution, and reproduction in any medium, provided the original author and source are credited. 
crosses the railway and is located in the city of Siping in Jilin Province of China. The bridge has a main span of $169 \mathrm{~m}$ and a side span of $90 \mathrm{~m}$, as shown in Figure 1. This bridge has a total of six traffic lanes, three in each direction. The height of the pylon is $75 \mathrm{~m}$ above the deck and the roadway width of the bridge is $36 \mathrm{~m}$. The height of the bridge girder is $3.4 \mathrm{~m}$. A total of 24 stay cables are used for the bridge and are spaced at $4 \mathrm{~m}$ between each other on the pylon. On the bridge deck, the cables are arranged at a spacing of $8 \mathrm{~m}$ on the main span and $6 \mathrm{~m}$ on the side span. The steel-concrete composite (SCC) section has a length of 2.25 $\mathrm{m}$ and located $11.5 \mathrm{~m}$ away from the pylon, as shown in Figure 1. The schematic of the SCC section of the bridge is shown in Figure 2.

\section{Fabrication of the Composite Joint Model}

The composite section considered in this study consists of three parts, including the multi-cell concrete box-girder, the SCC section, and the multi-cell steel box-girder. In order to reduce the effect of the local loads on the stress distribution, the lengths of the concrete girder and the steel girder are taken as $4.4 \mathrm{~m}$ and $5.4 \mathrm{~m}$, respectively, based on the Saint Venant's Principle. In the present study, a 1/4 scaled model of the composite section was fabricated in the laboratory, with the drawing shown in Figure 3. A thick concrete slab is added to each end of the composite section for the purpose of loading, as shown in Figure $3 \mathrm{a}$. The cross sections of the concrete box girder and the steel box girder are shown in Figures $3 \mathrm{~b}$ and $3 \mathrm{c}$, respectively.

The scaled model is $9 \mathrm{~m}$ in width and $0.85 \mathrm{~m}$ in height. The thickness of the top plate, bottom plate, side plate and the web of the steel girder are $6 \mathrm{~mm}, 6 \mathrm{~mm}, 4 \mathrm{~mm}$ and $5 \mathrm{~mm}$, respectively. These plates and webs were strengthened by stiffeners such as $U$ ribs and $T$ ribs, whose thickness ranges from $3 \mathrm{~mm}$ to $4 \mathrm{~mm}$. It should be noted that the minimum plate thickness that should be used is $3 \mathrm{~mm}$ in order to ensure the welding quality. Therefore, simplification was made on the configuration of some local components based on the criteria of equivalent cross-sectional area and equivalent moment of inertia. The concrete used in the SCC section is C50 steel fiber reinforced selfcompacting concrete while common C50 concrete was used for the concrete box girder. The thickness of the top, bottom and side plates of the concrete box girder is $150 \mathrm{~mm}$ while the thickness of the webs is $195 \mathrm{~mm}$.

To strengthen the connection between the steel girder and the concrete girder, headed studs, bearing plate and perfobond strips (PBL) were adopted in the SCC section model. The headed studs have a diameter of $13 \mathrm{~mm}$ and a height of $38 \mathrm{~mm}$. The number of headed studs was determined based on the principle of similarity. The bearing plates have a thickness of $10 \mathrm{~mm}$. The perfobond ribs are $150 \mathrm{~mm}$ in height and $5 \mathrm{~mm}$ in thickness. Holes with a diameter of $15 \mathrm{~mm}$ are drilled in the perfobond ribs. Steel strips with a diameter of $6 \mathrm{~mm}$ could pass the holes and provide extra bonding between the concrete and the steel ribs. Besides, 58 longitudinal prestressing tendons were arranged in the section with the positions marked in Figure $3 \mathrm{~b}$. The diameter of the steel strands used in the scaled model was the same as that in the bridge prototype while the number of strands was reduced to one-sixteenth of that used in the bridge.

Figure 4 shows the process of fabricating the scaled composite joint model. Once the strength of the concrete reached the design strength, the steel strands were prestressed to their design values with a hydraulic jack system, as shown in Figure 5.

The ingredients of the concrete used are listed in Table 1 . The only difference between the steel fiber-reinforced self-compacting concrete and the common concrete is that the former contains $27 \mathrm{~kg}$ of steel fibers per cubic meter of concrete. The properties of the steel fiber are shown in Table 2. The type of steel adopted is the Q345 steel that has design strength of $310 \mathrm{MPa}$ and a Young's modulus of $2.1 \times 105 \mathrm{MPa}$.

\section{Model Test}

\section{Loading procedure}

Based on the global structural analysis of the bridge by using the commercial software Midas Civil, the internal forces in the SCC section under the action of the dead load and the live load were calculated. The main internal forces include the axial force and bending moment. Two load levels were considered in the testing, including the design load

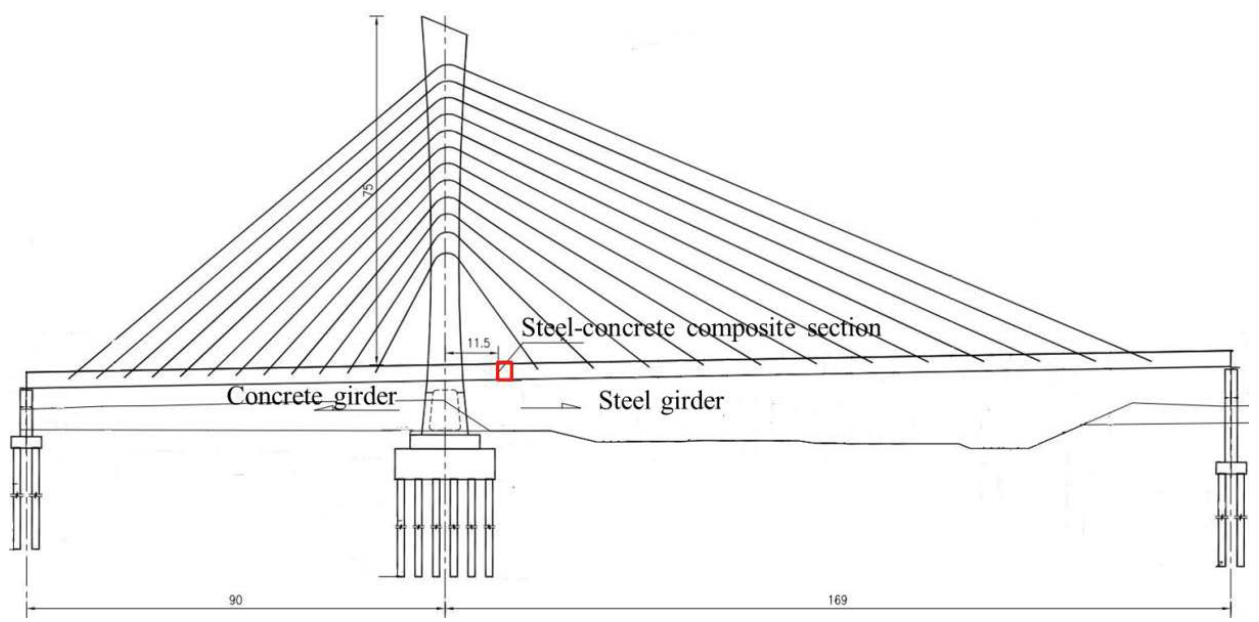

Figure 1: Elevation view of the bridge under consideration (unit: $\mathrm{m}$ ).

\begin{tabular}{|c|c|c|c|c|c|c|c|c|}
\hline Ingredient & Cement & Sand & Stone & Water & Admixture & Fly ash & Silica fume & Steel fiber \\
\hline Mass $\left(\mathbf{k g} / \mathbf{m}^{3}\right)$ & 450 & 828 & 829 & 156 & 14.4 & 54 \\
\hline \multicolumn{5}{|c}{ Table 1: Ingredients per cubic meter of concrete. } \\
\hline
\end{tabular}


Citation: Xu S, Yang YW, Deng L, Liu B (2017) Experimental Study on the Steel-Concrete Composite Girder Joint of a Single Pylon Cable-Stayed Bridge. J Steel Struct Constr 4: 139. doi: 10.4172/2472-0437.1000139

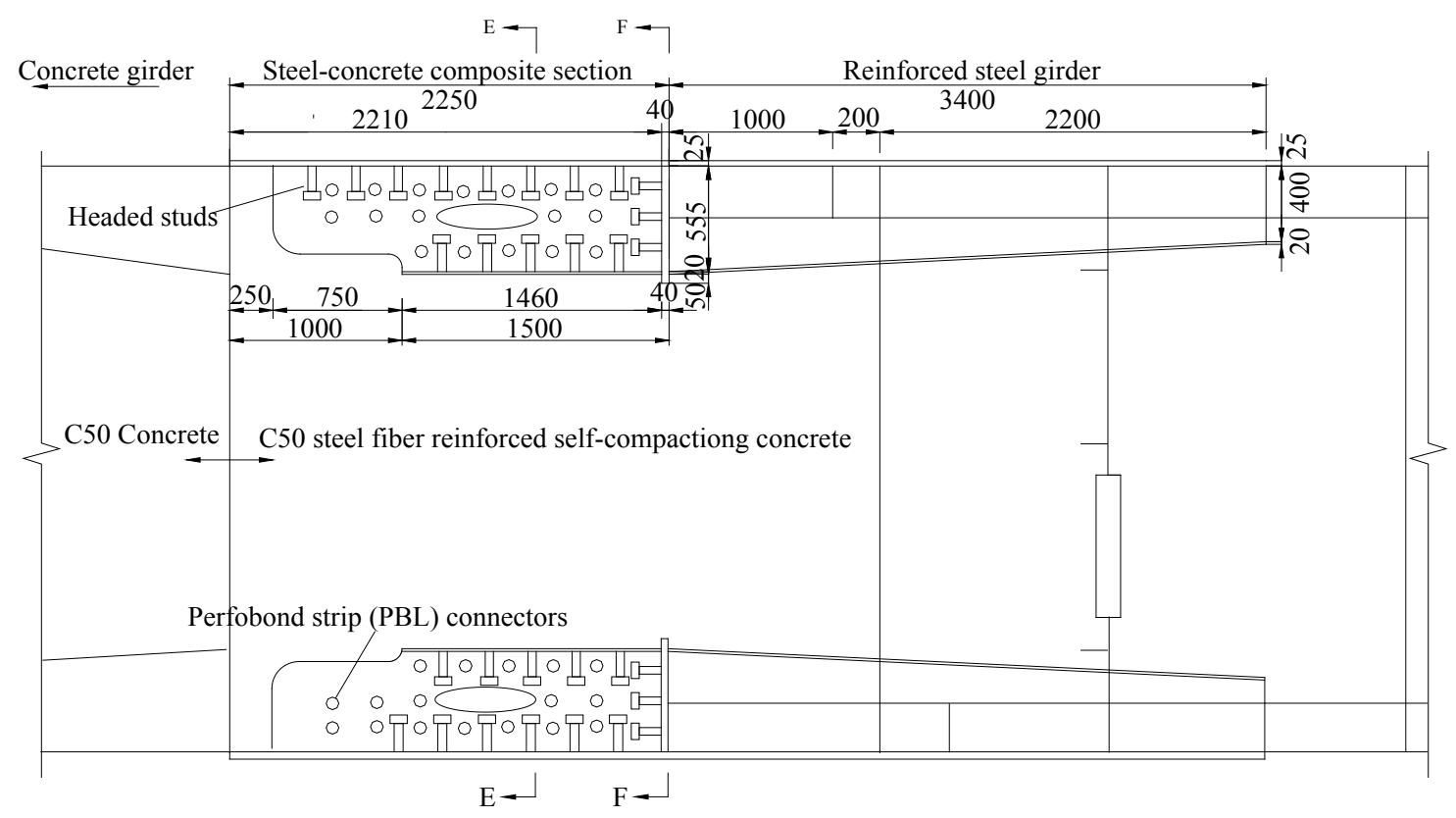

(a) Elevation view of the composite section .

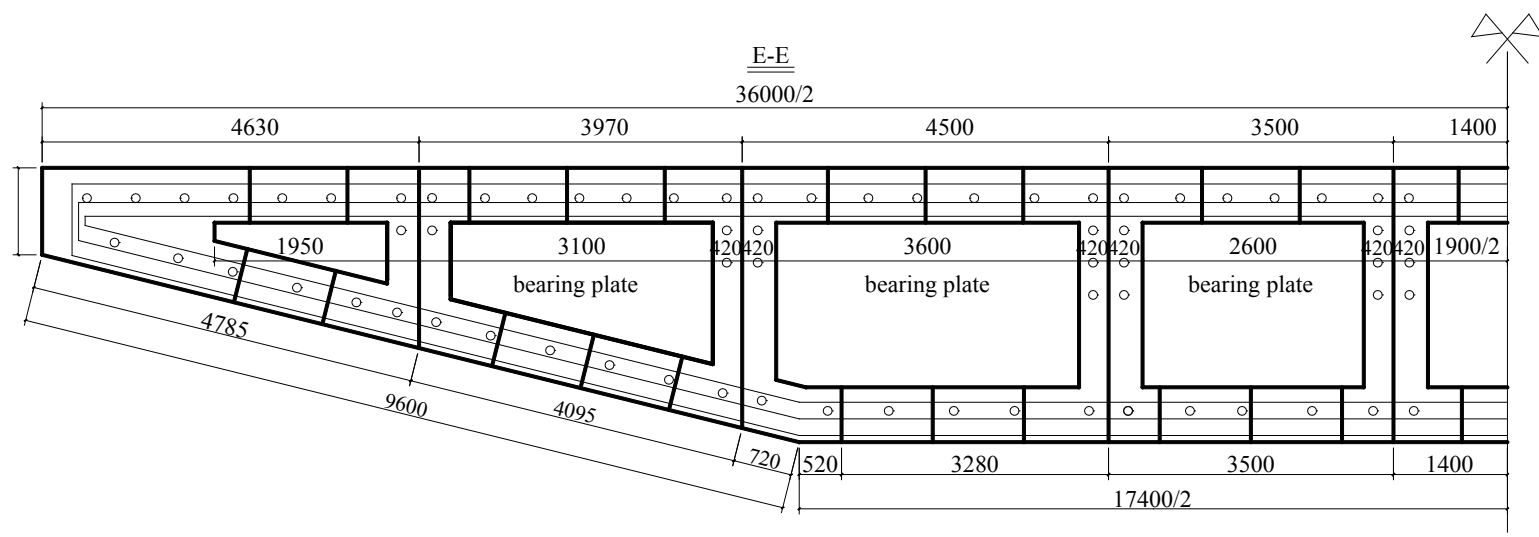

(b) Cross section of E-E.

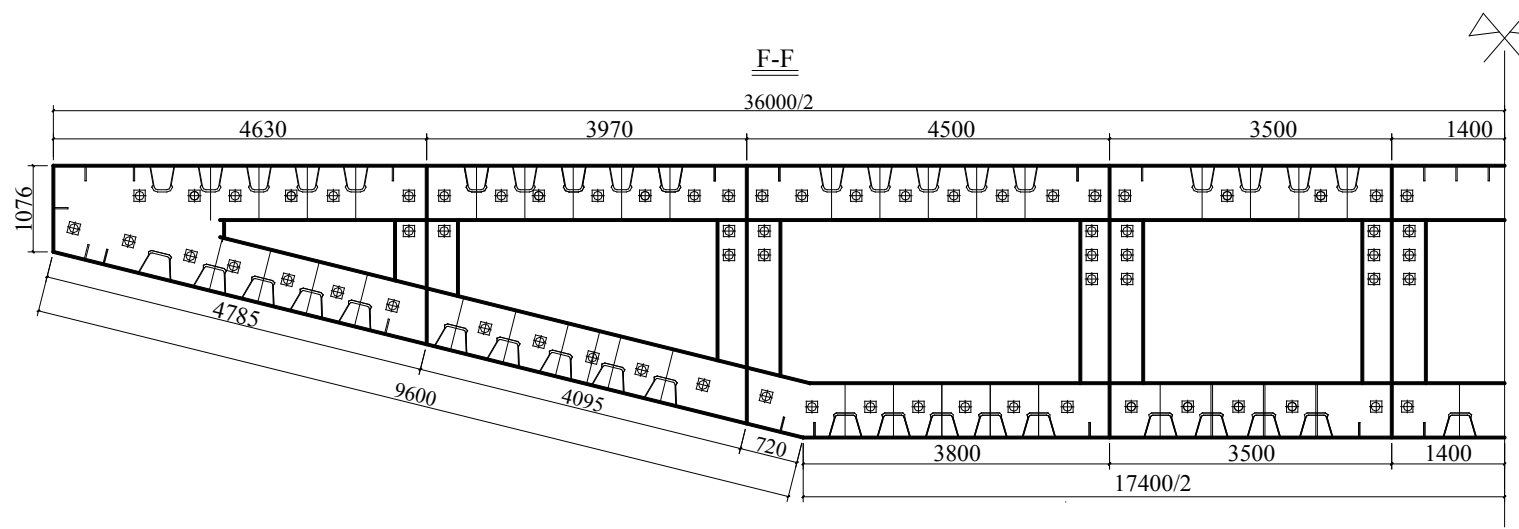

(c) Cross section of F-F.

Figure 2: Schematic of the steel-concrete composite section from the design drawing (unit: $\mathrm{mm}$ ) 
Citation: Xu S, Yang YW, Deng L, Liu B (2017) Experimental Study on the Steel-Concrete Composite Girder Joint of a Single Pylon Cable-Stayed Bridge. J Steel Struct Constr 4: 139. doi: 10.4172/2472-0437.1000139

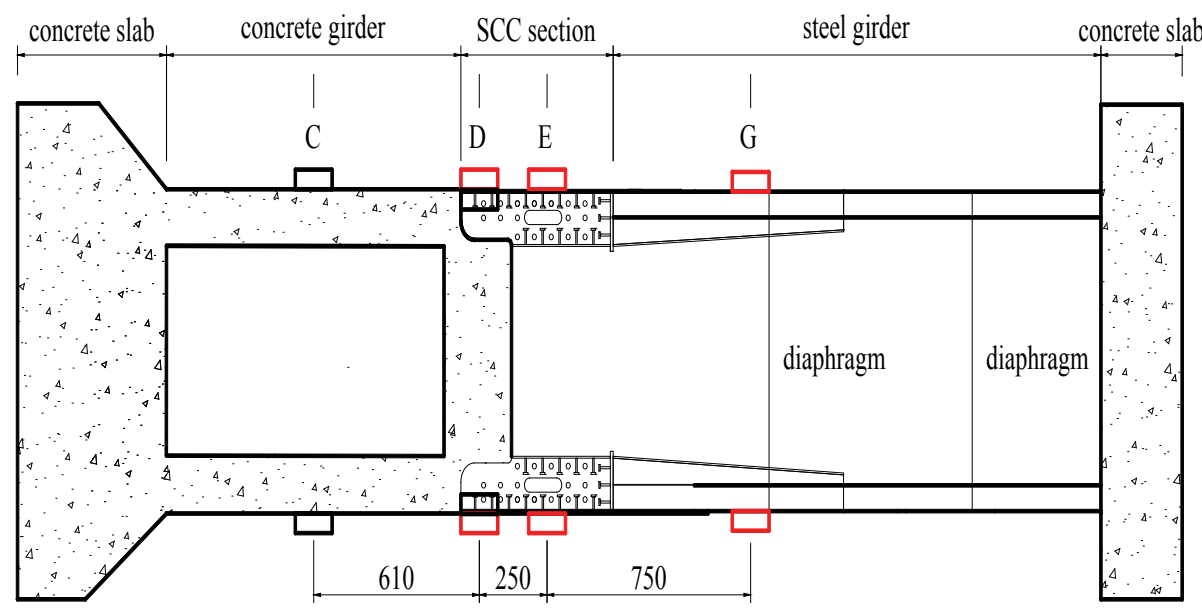

(a) Elevation view.

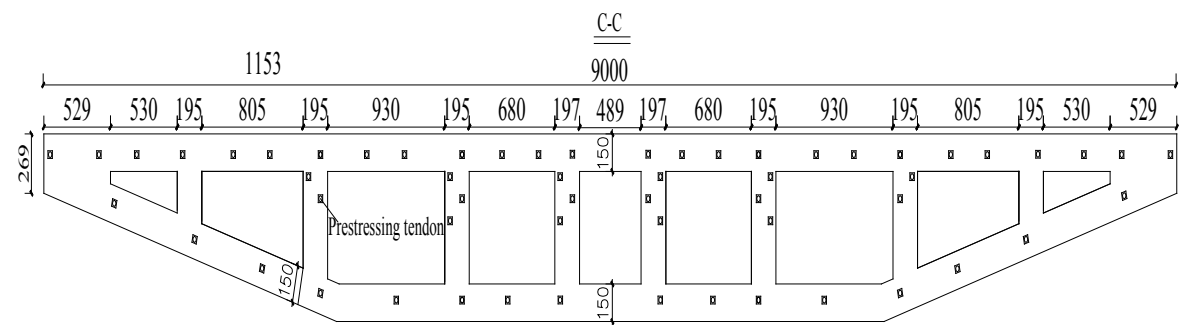

(b) Cross section of the concrete girder (C-C).

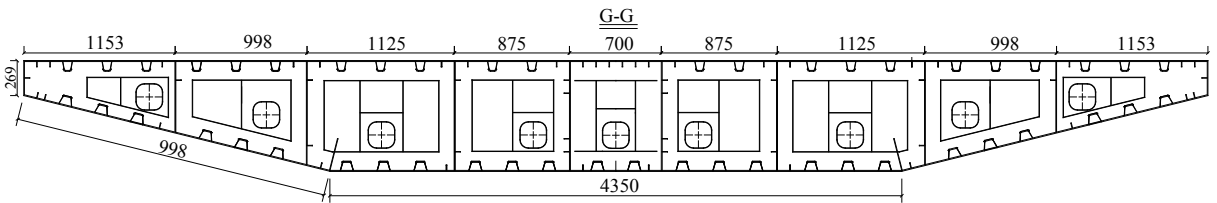

(c) Cross section of the steel girder (G-G).

Figure 3: Schematic of the scaled composite joint model (unit: $\mathrm{mm}$ ): (a) elevation view; (b) cross section of the concrete girder (C-C); (c) cross section of the steel girder (G-G).

\begin{tabular}{|c|c|c|}
\hline Length $(\mathbf{m m})$ & $\begin{array}{c}\text { Equivalent diameter } \\
(\mathbf{m m})\end{array}$ & Tensile strength (MPa) \\
\hline 29.9 & 0.7 & 465 \\
\hline
\end{tabular}

Table 2: Properties of the steel fibers used.

\begin{tabular}{|c|c|c|}
\hline \multirow{2}{*}{ Force } & \multicolumn{2}{|c|}{ Design load/1.7 times design load } \\
\cline { 2 - 3 } & Full-scale Prototype & Scaled Test Model \\
\hline Axial Force (kN) & $-1.08 \times 105 /-1.83 \times 105$ & $-6.70 \times 103 /-1.14 \times 104$ \\
\hline Bending Moment (kN·m) & $-5.00 \times 104 /-8.49 \times 104$ & $-7.80 \times 102 /-1.33 \times 103$ \\
\hline
\end{tabular}

Table 3: Force applied to the full scale SCC section and the scaled model.

and 1.7 times the design load. Table 3 lists the most critical loading combination that the full scale SCC section experiences and that was applied to the test model based on the similarity principle.

Based on the internal forces under the most critical loading condition as shown in Table 3, the behavior of the composite section under the two different levels of load was studied. The model was first loaded to the design load level during which the applied load was gradually increased to the design load step by step, with an increase

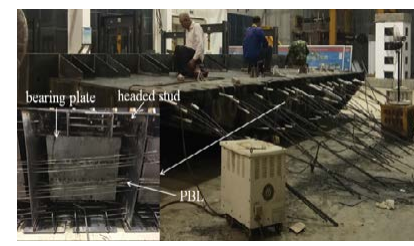

(a) Welding the steel girder.

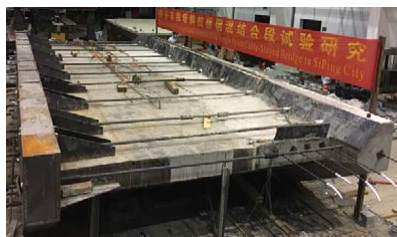

(c) Completed scaled model.

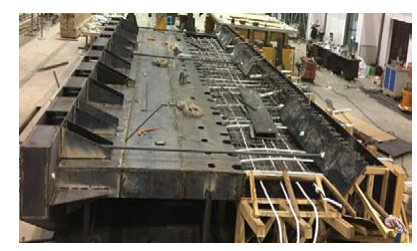

(b) Before casting concrete
Figure 4: Process of fabricating the test model. 
Citation: Xu S, Yang YW, Deng L, Liu B (2017) Experimental Study on the Steel-Concrete Composite Girder Joint of a Single Pylon Cable-Stayed Bridge. J Steel Struct Constr 4: 139. doi: 10.4172/2472-0437.1000139

of $10 \%$ of the design load each step. After the design load level was reached, the model was unloaded gradually in five steps, with a decrease of $20 \%$ of the design load each step. Then, the model was loaded again to 1.7 times the design load step by step, with an increase of $10 \%$ of the design load each step. The stresses of the model were measured at the end of each load step.

The axial force and bending moment were applied through a selfbalance system in which a total of 29 loading points were arranged across the section, as shown in Figure 6a. The force at each loading point in the cross section was applied by pulling the finished rolled rebar by a hydraulic jack at one end of the model, as shown in Figure $6 \mathrm{~b}$. A detailed loading plan was made before applying the loads. According to the loading plan, at the end of each load step the sum of the tension forces in the 29 finished rolled rebars will be equal to the total axial force to be applied to the section. In addition, the bending moment to be applied can also be achieved by adjusting the tension forces in the

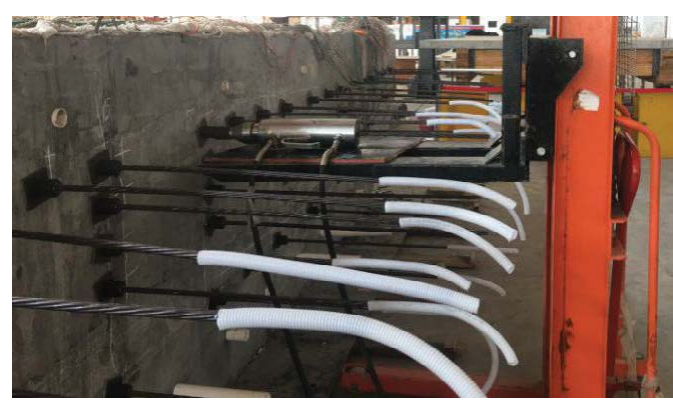

Figure 5: Prestressing the steel strands. finished rolled rebars in the upper and lower rows while maintaining the total axial load in the cross section.

\section{Measurement arrangement}

Four key sections, namely, C, D, E, G as shown in Figure 7a, were selected to study the structural performance of the joint model. To measure the stresses in the steel girder, strain gauges were attached to the surface of the top and bottom plates of the steel girder. For the concrete girder section, strain sensors were embedded in the concrete or attached to the concrete surface. The relative slip between the concrete and the steel was measured by a pair of sensors close to each other. One strain gauge was attached to the inner surface of the steel plate while the other was embedded in the concrete close to it. If the strains measured by the two sensors are different, it indicates that the deformation between the steel and the concrete girder is not coordinated and relative slip may have occurred between the two materials.

\section{Test Results}

\section{Stresses on the plate surface}

Figure 8 shows the relationship between the magnitude of the load applied (normalized by the design load) and the measured stresses at different measurement locations of the section. From Figure 8, it can be seen that the stresses at both the steel and the concrete sections increased almost linearly with the increase of the load applied. It is noted that the test model was still in the linear-elastic stage even under the action of 1.7 times the design load. Besides, the stress decreased along the longitudinal direction from section G-G to section D-D in the steel girder and slightly increased from section D-D to section a

b

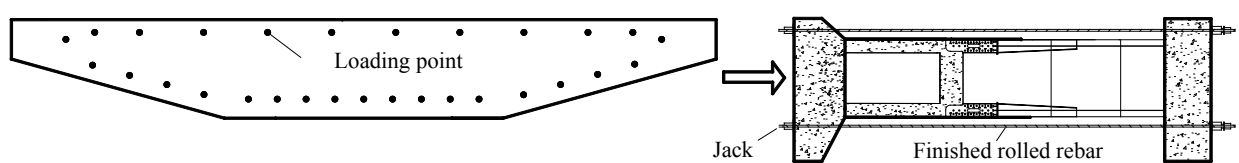

Figure 6: (a) The loading system Loading points, (b) the hydraulic jack system.

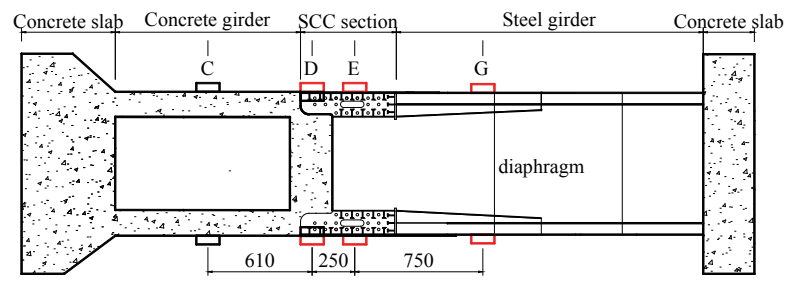

(a) Elevation view

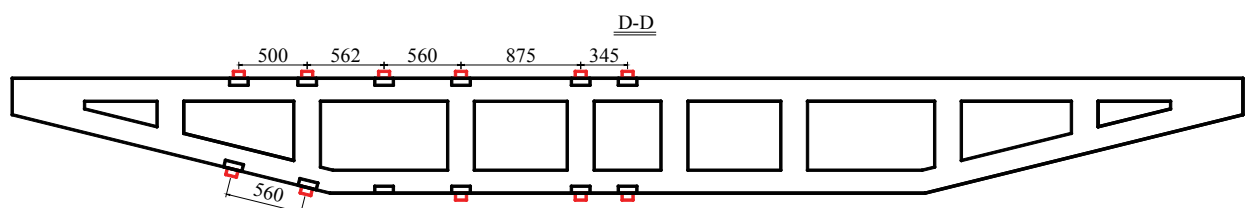

(b) Cross section (D-D).

Figure 7: Sensor arrangement (unit: $\mathrm{mm}$ ). 
Citation: Xu S, Yang YW, Deng L, Liu B (2017) Experimental Study on the Steel-Concrete Composite Girder Joint of a Single Pylon Cable-Stayed Bridge. J Steel Struct Constr 4: 139. doi: 10.4172/2472-0437.1000139

$\mathrm{C}-\mathrm{C}$ in the concrete girder. It should be noted that the stress values in Figure 8 are the average values of the six stresses measured at the top or bottom plate of each section shown in Figure $7 \mathrm{~b}$. It should also be noted that these stress values do not contain the stress caused by the pre-stressing tendons which led to an additional compressive stress of around $4 \mathrm{MPa}$ in the concrete girder.

It can be seen from Figure 8a that under the action of 1.7 times the design load, the compressive stress at the bottom plate in the steel girder decreased from 77.54 MPa at section G-G to $33.44 \mathrm{Mpa}$ at section E-E and then to $26.32 \mathrm{MPa}$ at section $\mathrm{D}-\mathrm{D}$, while Figure $8 \mathrm{~b}$ shows that the compressive stress in the concrete increased slightly from section D-D to section $\mathrm{C}-\mathrm{C}$. This shows that the axial force and the bending moment can be transferred smoothly between the concrete girder and the steel girder through the steel-concrete composite section.

The stresses in the steel girder and the concrete girder at different transverse positions under the two levels of loads are shown in Figures 9 and 10, respectively. From Figures 9 and 10, it can be observed that the stresses in both the steel girder and the concrete girder fluctuate along the transverse direction and the magnitude of fluctuation of the stress at different transverse position in the steel girder is larger than that in the concrete girder. The reason for the larger fluctuation of

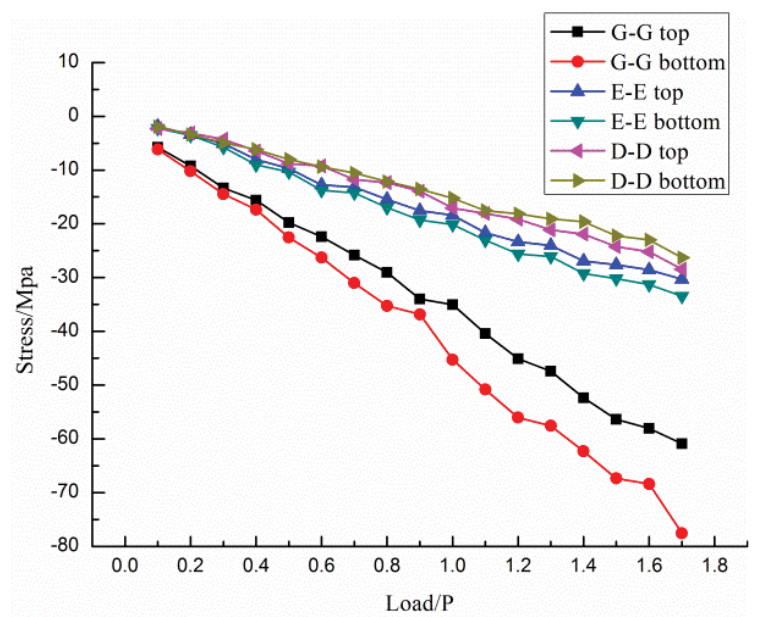

(a) Steel plate.

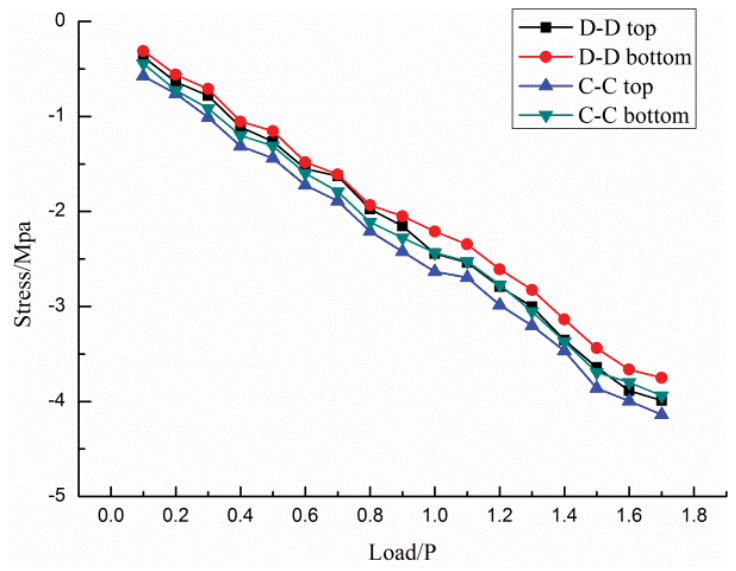

(b) Concrete section.

Figure 8: Load-stress curves.

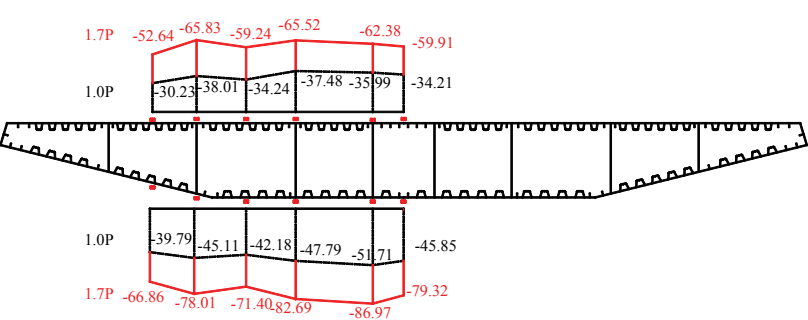

(a) Section G-G.

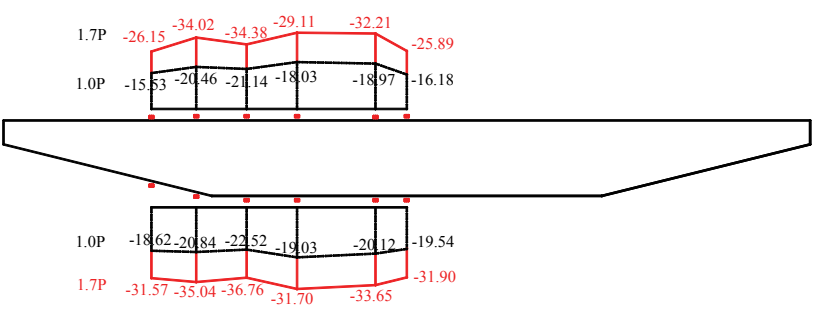

(b) Section E-E.

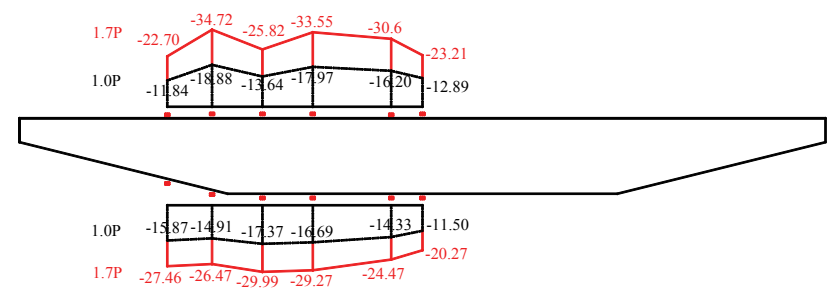

(c) Section D-D.

Figure 9: Stress in the steel plate at different transverse positions: (a) section G-G; (b) section E-E; (c) section D-D.

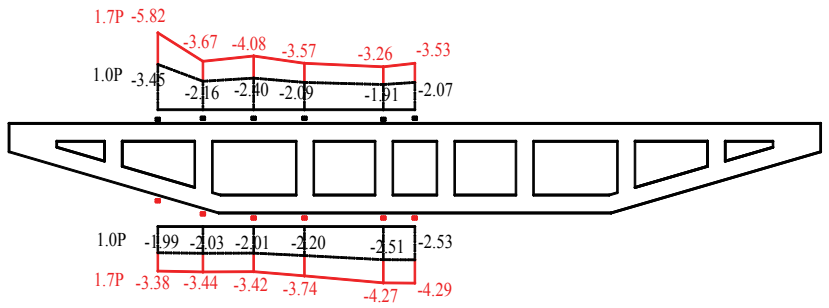

(a) section D-D.
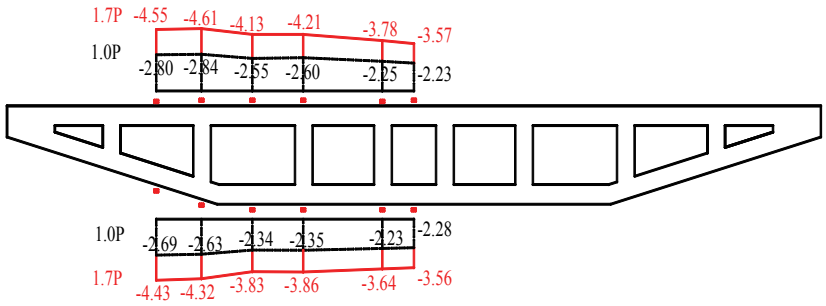

(b) section C-C.

Figure 10: Stress in the concrete at different transverse positions: (a) section D-D; (b) section C-C. 


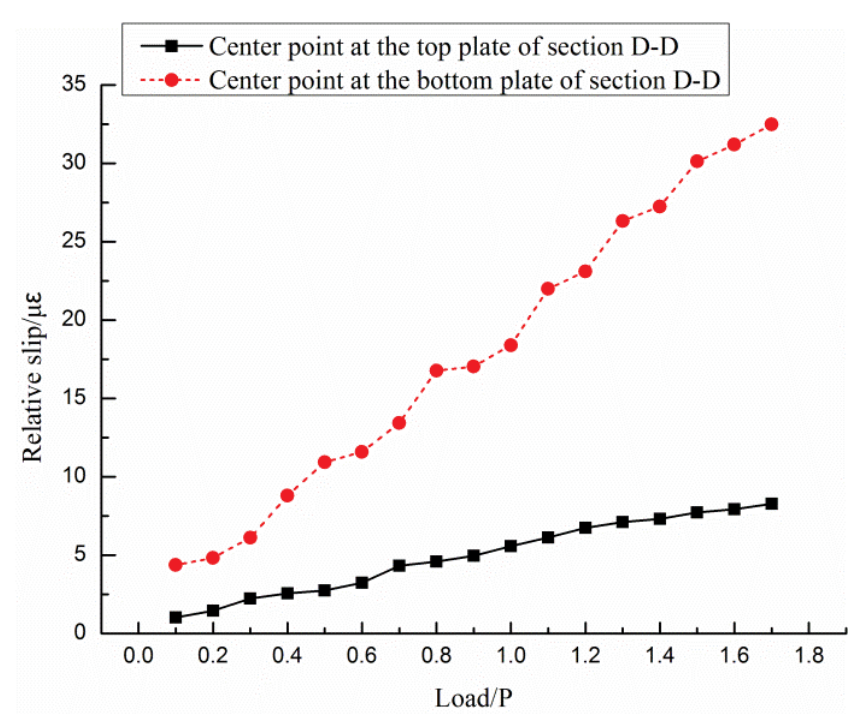

Figure 11: Relative slip between the steel and concrete in the composite section.

stress at different transverse positons in the steel section may be due to the variation of transverse rigidity resulted from the ribbed stiffeners such as $\mathrm{U}$ ribs and $\mathrm{T}$ ribs. Similar trend was also observed in other studies [7].

\section{Relative slip between the steel and concrete}

Six pairs of sensors were installed at section $\mathrm{D}$-D to investigate the relative slip between the steel and concrete in the composite section. Figure 11 shows the relative slip between the steel and concrete near the top and bottom plates at section D-D. It can be seen from Figure 11 that the relative slip between the steel and concrete increases linearly with the increase of the load applied and that the relative slip between the steel and concrete at the bottom plate is larger than that at the top plate due to the action of the hogging moment experienced by the SCC section. The maximum relative slip between the steel and the concrete was $35 \mu \varepsilon$ under 1.7 times the design load, which indicates that the relative slip between the steel and concrete girder occur but the value is small.

\section{Conclusion}

In the present study static test on a scaled composite girder joint model was conducted in the laboratory to examine the performance of the steel-concrete composite joint of a hybrid girder cable-stayed bridge with single pylon. A self-balance system was used to apply the axial force and bending moment, in which the bending moment to be applied was achieved by adjusting the tension forces applied to the upper and lower cross sections while maintaining the total axial force. Based on the results from the test, the following conclusions can be drawn:

1. The maximum stresses in the steel and concrete components are within the allowable limits. The maximum compressive stresses occurred at the steel section of the girder rather than the steel-concrete composite section because the area of the steel-concrete composite section is larger than that of the steel section of the girder.

2. The stress in the steel and concrete girder fluctuates along the transverse direction, likely due to the variation of the local rigidity across the sections.

3. Relative slip between the steel and the concrete does occur under the design load but the slip value is small.

4. The findings from the study indicate that the axial force and the bending moment can be transferred smoothly between the concrete girder and the steel girder through the steel-concrete composite section. Those findings provide useful reference and guidance for the design and testing of steel-concrete composite joints in hybrid girder cable-stayed bridges.

\section{References}

1. Virlogeux M (1999) Recent evolution of cable-stayed bridges. Engineering Structures 21: 737-755.

2. He J, Liu Y, Chen A, Yoda T (2010) Experimental study on inelastic mechanical behaviour of composite girders under hogging moment. Journal of Constructional Steel Research 66: 37-52.

3. Cheng X, Nie X, Fan J (2016) Structural Performance and Strength Prediction of Steel-to-Concrete Box Girder Deck Transition Zone of Hybrid Steel-Concrete Cable-Stayed Bridges. Journal of Bridge Engineering 21: 04016083.

4. Chen K, Wang J, An Q (2006) Model tests on steel-concrete joining section of main girder of a cable-stayed bridge. China Civil Engineering Journal 39: $86-90$

5. He S, Fang Z, Fang Y, Liu M, Liu L, et al. (2016) Experimental study on perfobond strip connector in steel-concrete joints of hybrid bridges. Journal of Constructional Steel Research 118: 169-179.

6. Xiao L, Li X, Ma ZJ (2017) Behavior of Perforated Shear Connectors in SteelConcrete Composite Joints of Hybrid Bridges. Journal of Bridge Engineering 22: 04016135

7. He J, Liu Y, Pei B (2014) Experimental Study of the Steel-Concrete Connection in Hybrid Cable-Stayed Bridges. Journal of Performance of Constructed Facilities 28: 559-570.

8. Soty R, Shima H (2013) Formulation for shear force-relative displacement relationship of L-shape shear connector in steel-concrete composite structures. Engineering Structures 46: 581-592.

9. Costa-Neves LF, Figueiredo JP, Vellasco PCGdS, Vianna JdC (2013) Perforated shear connectors on composite girders under monotonic loading: An experimental approach. Engineering Structures 56: 721-737.

10. Kim SE, Nguyen HT (2012) Evaluation of the connection efficiency of hybrid steel-concrete girder using finite element approach. International Journal of Mechanical Sciences 61: 8-23.

11. Kim SE, Nguyen HT (2010) Finite element modeling and analysis of a hybrid steel-PSC beam connection. Engineering Structures 32: 2557-69.

12. D'Antimo M, Demonceau JF, Jaspart JP, Latour M, Rizzano G (2017) Experimental and theoretical analysis of shear bolted connections for tubular structures. Journal of Constructional Steel Research 138: 264-82.

13. Kim SH, Lee CG, Kim SJ, Won JH (2011) Experimental study on joint of spliced steel-PSC hybrid girder, part II: Full-scale test of spliced hybrid I-girder Engineering Structures 33: 2668-82.

14. Ahn JH, Lee CG, Won JH, Kim SH (2010) Shear resistance of the perfobond-rib shear connector depending on concrete strength and rib arrangement. Journal of Constructional Steel Research 66: 1295-307. 